Zeszyty Naukowe Politechniki Częstochowskiej

Zarządzanie Nr 28 t. 2 (2017) s. 87-112

dostępne na: http://www.zim.pcz.pl/znwz

\title{
MANAGING SILESIA VISUAL IDENTITY THROUGH REGIONAL AND LOCAL LOGO DESIGN
}

\author{
Anna Adamus-Matuszyńska1, Piotr Dzik ${ }^{2}$ \\ 1University of Economics in Katowice, Economics Department \\ ${ }^{2}$ The Academy of Fine Arts in Katowice, Economics Department
}

\begin{abstract}
Developing coherent and comprehensive regional and city brands is of vital importance for places, as branding can contribute to the success achieved in tourism, investment and thus the region itself. There seems to be a recognizable gap in the literature regarding the application of visual signs used in place marketing that should present a city, region or country. The paper outlines the most important challenges as well as faults in management of visual identity in Silesia region, in Poland. The research attempts at identifying and analysing logos of cities and communes of the Silesian Voivodship (pol. województwo śląskie). The main purpose of this exploration is to describe the Silesian visual identity through practiced visual signs called logos.

The authors try to find solutions for the following research questions:

1. What trends are typical for visual presentation of the cities in the Silesian Voivodship?

2. What image of the region is presented when exploring logos of the Silesian cities?

3. How is logo practiced in public management in the Silesia Voivodship?

Content analysis was used to obtain visual identity of the cities. First the authors tried to collect all logos and then analysed them using the Per Mollerup's taxonomy. The results of the study illustrate how self-government institutions, which are responsible for promotion of the place, portray the Silesian cities in marketing communication.
\end{abstract}

Keywords: visual identity, logo, brand, place marketing, visual identity management

DOI: $10.17512 /$ znpcz.2017.4.2.08

\section{Introduction}

The aim of the article is to analyse the process of visual identity management of a place and evaluate its implementation in terms of activities undertaken by local government units in the Silesian province through the development and implementation of the logo as a basic element of the visual identity. The logo is used both for marketing purposes and development of the site. The methods employed in the process included literature studies on the identity management space and the process of its promotion, analysis of documents related to this process and their publications on the cities, municipalities and counties websites.

The literature analysis of the place as a subject matter indicates that the experts in various fields applying various theoretical approaches and research tools study

${ }^{1}$ This article is a part of the project funded by the University of Economics in Katowice called: Management of information and communication in public institutions under the scientific guidance by dr hab. Agata Austen. 
it. Sociologists, economists, geographers, marketing theorists, management researchers try to scrutinize all issues associated with 'the place'. In principle, each of these approaches is adopted in two arguments. Firstly, there is the identity of the visual space, understood as a set of characteristics that allow recognize the place position and differentiate it from others. Secondly, it is necessary to manage this visual identity to grant both the local community and the external environment the location meaning. Corporate design is a form of the place self-presentation. This identification characterizes and distinguishes specific characteristics of the sites. Visual identity management of the given place needs to substantiate the basic elements in the design program, presented in the form of a manual which contains rules for the use and application of visual identity.

In summary, the place (city, region, country) manages the process of intentional creation and propagation of images (visual identity), thorough the active use of promotional logo.

\section{Current state of art}

Territorial or place marketing, as a sub-discipline of marketing began to be distinguished in the eighties of the 20th century (Hanna, Rowley 2011; Ashworth, Kavaratzis 2009; Kavaratzis 2009) and has recorded several phases of its development (Kavaratzis 2004; Skinner 2008; Kavaratzis, Ashworth 2008; Borglund, Olsson 2010; Hankinson 2015). In 2004 theoreticians and practitioners began to apply the concept of 'brand' (Lucarelli, Berg 2011) into analysis and practice of territorial marketing. Now it seems that such an approach dominates the literature. Considering the fact that both the 'brand' (Keller 2003; de Chernatony, McDonald, Wallace 2011) and 'place' (Hanna, Rowley 2008; Szromnik 2012) are concepts still waiting for clear recognition, it is not strange that in the literature there is at least a dozen of models of place branding. The authors of the presented paper divide those models into three groups: 1. 'limited control models', 2. 'general marketing models' and 3. 'models of adjusted tools'. In case of the first group of models the attention is focused on the specific place brand in relation to product brands and corporate specificity, resulting from the limited control over individual elements of the marketing mix. As a result, the place (a town or a region) must build its own brand in cooperation and partnership with numerous independent entities (businesses, NGOs, other places). This group may include the following models: Philip L. Pearce (Pearce 2005, p. 91), Robert Govers and Frank M. Go (Govers, Go 2005), and the Polish approach represented by the idea of Marek Bańczyk (Bańczyk 2009, p. 209). The general marketing models refer to the assumption that the place brand conceptually does no differ from corporate brand and one can apply traditional business marketing method to every brand. Supporters of this approach are among others Per Mollerup (Mollerup 2013, p. 46), Matthew Healey (Healey 2008, p. 8-9), Fallon advertising agency (Fallon, Senn 2007, p. 23), Mihalis Kavaratzis and George Ashworth (Kavaratzis, Ashworth 2005), and Wally Olins (Olins 2009, p. 28). The model of adjusted tools is a concept seeking specificity of cities, regions and countries when introducing 
marketing tool which means that typical characteristics of the place together with identity are considered before an idea of brand is employed. The Simon Anholt's theory is the most typical in this group (Anholt, Hildreth 2005, p. 30). Graham Hankinson (relational model) (Hankinson 2004), Teemu Moilanen and Seppo Rainisto (DEBRA process model) (Moilanen, Rainisto 2009, p. 117), Myfanwy Trueman and Nelarine Cornelius (Trueman, Cornelius 2006), Marcello Risitano (Risitano 2006), Keith Dinnie (Dinnie 2014, p. 14), Jasper Eshuis and Erik-Hans Klijn (Eshuis, Klijn 2012, p. 5) developed their own concepts of referring to the marketing tools which cannot be included into any of the previous models.

Polish literature is dominated by an approach that combines characteristics of the place (characteristic features of the place identity) with communication (creation of place identity) and which is based on the work of Alfred Töpfer and Robert Müller. This idea appeals to many authors, including Andrzej Szromnik (Szromnik 2012, p. 148-152), Ewa Glińska, Magdalena Florek oraz Anna Kowalewska (Glińska, Florek, Kowalewska 2009, p. 39) or Anna Adamus-Matuszyńska (Adamus-Matuszyńska 2012, p. 39-40). An important problem often cited in these references is that theoretical models are not based on robust empirical database (Skinner 2008; Lucarelli, Berg 2011).

At about the same time when territorial marketing arouse, the concept of New Public Management (NPM) began to gain popularity, which led to the reflection on integrated brand management and the place itself. The idea of new public management (NPM) in the late 80s of the last century influenced and still does influence the reform of the public sector, leading it in the direction of methods and management techniques specific to the private sector. As Frączkiewicz-Wronka (Frączkiewicz-Wronka 2008, p. 21) pointed out: "According to the NPM, management of a public organisation should be directed at innovation, dynamism, and entrepreneurship. They are also expected to develop flexible skills". As a result, more and more practical knowledge and experience of managers from the private sector generate changes in public management (Austen, Frączkiewicz-Wronka 2012, p. 30). Local government develop activities which are targeted on the places promotion simultaneously with solving the specific problems of local and regional communities expected to be undertaken. At the same time they treat them as factors significantly influencing the development of community and the place itself. Local governments manage today cities and regions in a manner similar to business management, e.g. through risk-taking, innovations, promotion and actions that deliver tangible benefits (Hubbard, Hall 1998). So one can assume that public management in local government also means 'place brand' management.

Regardless of the brand definition there is no doubt that a brand has much in common with the trademark because a person does not perceive the brand itself but perceives (reads) the signs (Lash, Lury 2011, p. 28). It means that by these signs researchers may examine the place brands. Hence, authors of the article decided to collect and analyse logos (signatures) of places (cities and municipalities in the province of Silesia), and finally organise them according to a chosen typology.

The authors take into account the conceptual model presented in the Figure 1. 


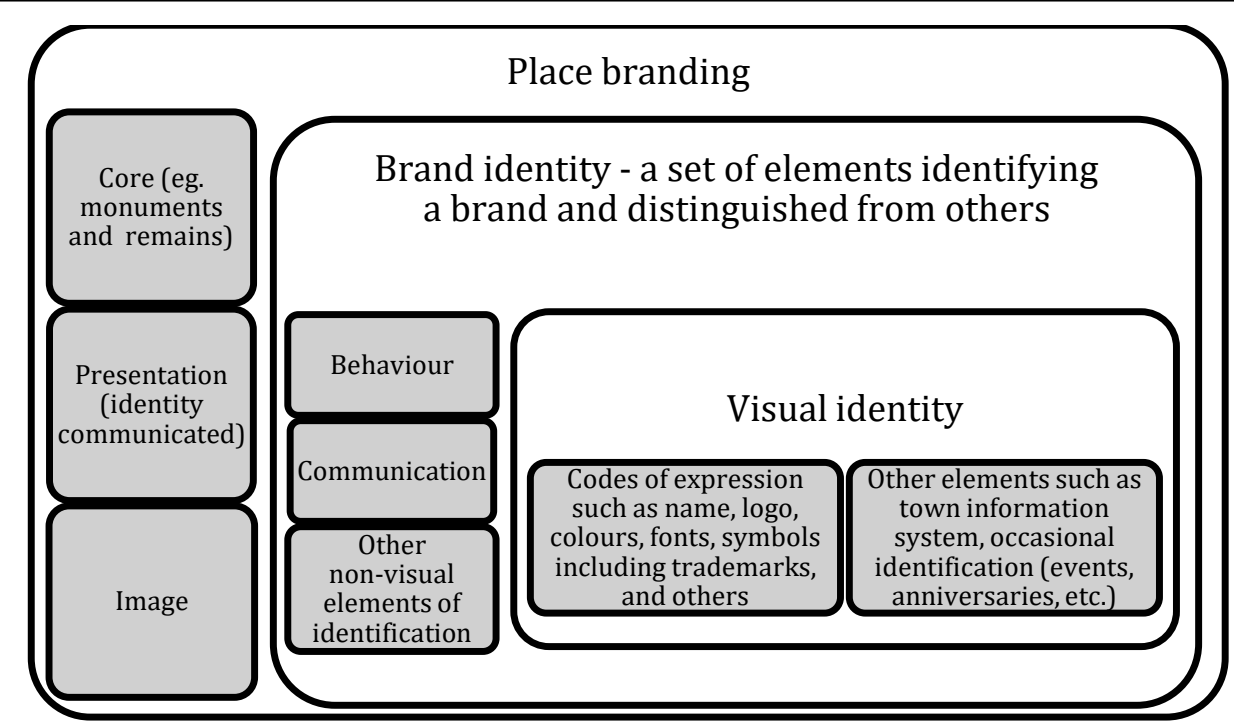

Figure 1. Visual identity in a broader concept

Source: Author's own research

However, there is another theoretical problem - how to define the object that means the 'mark'. The authors follow the Per Mollerup's definition: The term 'trademark' refers to any letter or combination of letters, pictorial sign, or a non-graphic, even non-visual, sign, or any combination of these used by an organization or by its members to identity communications, property and products or that certify products and that distinguish them from those of others (Mollerup 2013, p. 99).

Generally territorial marketing is a very eclectic discipline that is multidisciplinary nature. What is more, it does not include many explanatory articles and many questions still remain unanswered (Vuignier 2016, p. 38).

\section{Methods of analysis}

Considering characteristics of sings used by a given place (city, region or country) two aspects should be clarified:

1. In practice, apart from visual symbols there are also non-visual signs practised. For example, in Poland one of the most common is a bugle call, but also there are urban songs or other popular music signals. This group of characters is not analysed in this article.

2. A graphic sign of the place (place mark), that was revealed by the initial query and the authors' current study, takes the form of 'signature', as it is defined by Alina Wheeler who claims that a graphic sign consists of three elements (Wheeler 2009, p. 50):

a. a graphic sign called logo,

b. a logotype which means a place name saved in a standard written format, 
c. a slogan ${ }^{2}$ constantly assigned to the name and graphic sign (logo) and presented together with them.

\section{Research method}

The authors of the study used content analysis as a research method. Its application requires the following procedure (Rose 2010, p. 83-99):

a. finding images ${ }^{3}$

b. devising categories for coding

c. coding images

d. analysing the results.

\section{Finding images}

This article examines all promotional signatures of counties, cities and municipalities in the Silesian Voivodship. The following information has been taken into account:

a. Upper Silesia encompasses 19 townships, 17 administrative districts, 36 counties together representing approx. $10 \%$ of counties in Poland.

b. Silesian Voivodship consists of 167 municipalities, i.e. approx. $6 \%$ of communes in Poland.

c. The surveyed self-government units are of different sizes (from the cities with a few hundred thousand inhabitants to small municipalities).

The visual presentations were sought on official websites of townships, offices of the cities and municipalities, in Bulletins of Public Information, in promotional materials of towns and municipalities (e.g. maps, guidebooks, calendars). The authors also used personal contacts with employees of the promotion offices. In some cases (e.g. Gliwice, Zabrze, Siewierz, Milówka) authors participated in various projects related to the visual identification of the region.

\section{Devising categories for coding}

Effective taxonomy should be characterised by the following features (Mollerup 2013, p. 100):

I. The classes should be differentiated with clear distinction between them.

II. The characteristics of every category should be consistent.

III. The classes should exclude each other, and a particular description should fit exclusively into one category.

IV. The classes should cover the entire spectrum of possible entries.

$\mathrm{V}$. The classes must be relevant to the purpose of the taxonomy.

\footnotetext{
${ }^{2}$ Wheeler uses both English terms: slogan and tagline without detailed explanation what differences are between these two terms.

${ }^{3}$ Image in the Gillian Rose book has different meaning than in Polish language. In her analysis image means a visual picture.
} 
For the purposes of this article the Per Mollerup's taxonomy has been selected. That choice was made due to the following reasons:

a. He is a well-known practitioner, the author of many projects and at the same times a theorist and university lecturer who developed the taxonomy.

b. The taxonomy has operated in the global circulation for several years, the book in which it is explained was reprinted and revised.

c. The taxonomy is based on a clear theoretical construction and refers, inter alia, to the work of Ferdinand de Saussure and Charles Sanders Peirce as well as other communication theorists.

d. The taxonomy works in practice. Its author himself tested the content of the book "Marks of excellence".

e. The taxonomy is well known among Polish graphic designers.

Numerous advantages and professional position of the Mollerup's taxonomy makes it useful for representatives of other social sciences. The authors tested the taxonomy in their other research projects.

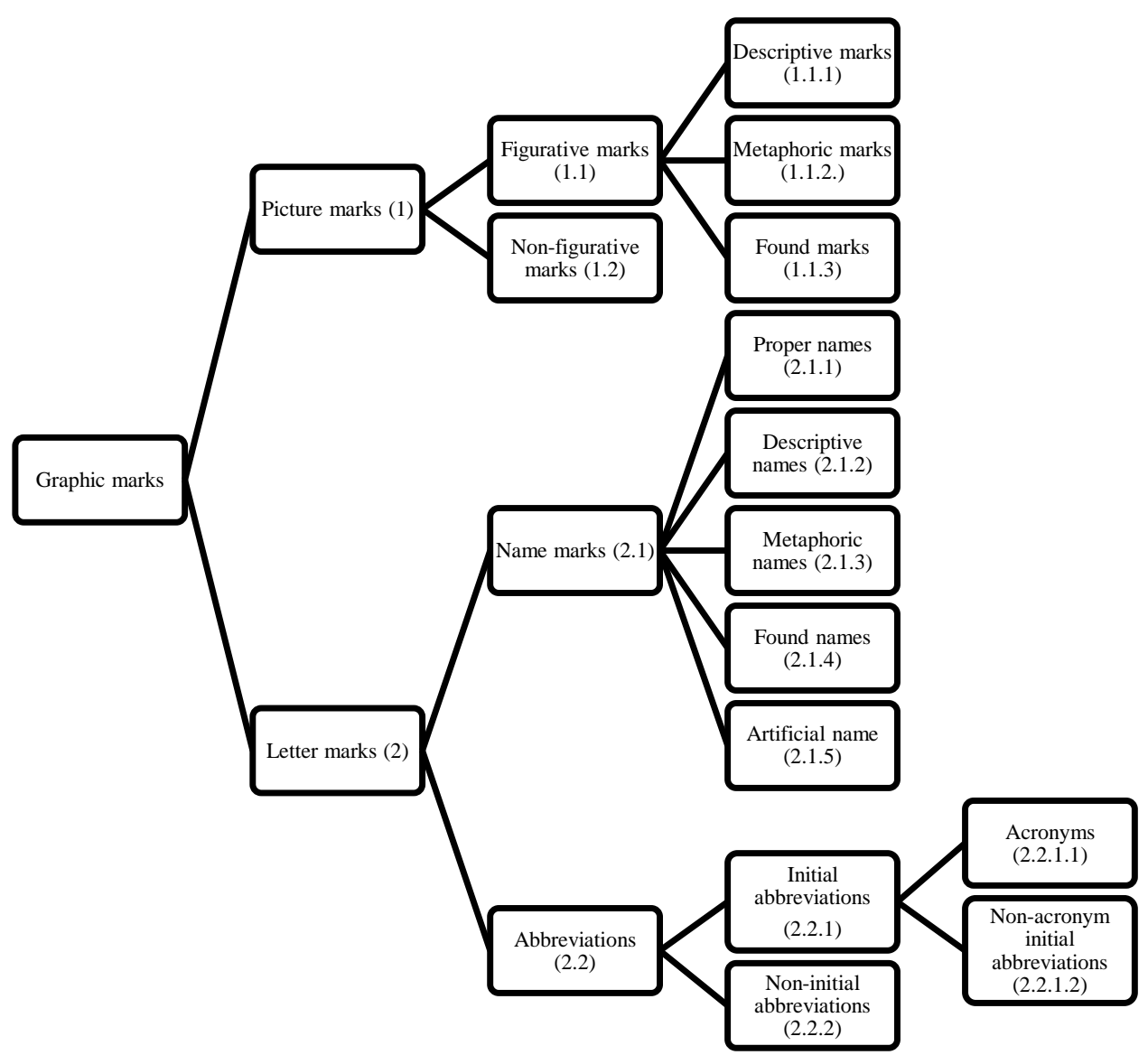

Figure 2. Mollerup's taxonomy

Source: (Mollerup 2013, p. 101) 
In the original Mollerup's taxonomy the category of non-graphic marks, i.e., signs having different than visual form, is included (Mollerup 2013, p. 101) but not taken into account in this paper ${ }^{4}$. The signs that are other than visual (such as bugle calls or songs) deserve deeper analysis, however they require greater competence from the researchers.

The terms 'found marks' and 'artificial name' require additional explanation. In the Mollerup's classification the term 'found' is reserved for names and signs that exist in reality, although their relationship with a given place does not carry any associations. The term 'artificial names' refers to neologisms created for the purpose of identity creation.

The analysis shows that pictures (pictures marks in the Mollerup's taxonomy) are the subject of research, and the cities' names presented as visual signs will be included into 'proper names' class of trademarks.

\section{Coding images}

Table 1. Cities

\begin{tabular}{|c|c|c|c|}
\hline No. & Place & Logo & Taxonomy \\
\hline 1. & Bielsko-Biała & & $\begin{array}{l}\text { Non-figurative mark } \\
\text { that can be classi- } \\
\text { fied as acronym as } \\
\text { well }\end{array}$ \\
\hline 2. & Bytom & & $\begin{array}{l}\text { Descriptive mark - } \\
\text { what one may } \\
\text { conclude reading } \\
\text { the description of } \\
\text { the visual identity }\end{array}$ \\
\hline 3. & Chorzów & wprawia w ruch & $\begin{array}{l}\text { Proper name with } \\
\text { the slogan }\end{array}$ \\
\hline 4. & Częstochowa & $\begin{array}{l}\begin{array}{l}\text { jasne, ze } \\
\text { CZESTOCHOWA, } \\
\text { it's clear }\end{array} \\
\end{array}$ & $\begin{array}{l}\text { Proper name with } \\
\text { the slogan }\end{array}$ \\
\hline
\end{tabular}

\footnotetext{
${ }^{4}$ Mollerup in his book does not make the detailed analysis of the "non-graphic" or "non-visual" marks. A general term "device" is proposed by this author (Mollerup 2013, p. 98-99, 114).
} 
Anna Adamus-Matuszyńska, Piotr Dzik

\begin{tabular}{|c|c|c|c|}
\hline 5. & Dąbrowa Górnicza & & Non-figurative mark \\
\hline 6. & Gliwice & & Descriptive mark \\
\hline 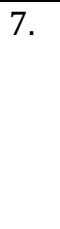 & Jaworzno & Jaworzno & Non-figurative mark \\
\hline 8. & Jastrzębie Zdrój & JASTRZĘBIE-ZDRÓJ & Found mark \\
\hline 9. & Katowice & $\begin{array}{c}\text { KATOWICE } \\
\text { dla odmiany }\end{array}$ & Non-figurative mark \\
\hline 10. & Mikołów & MIKOtOW & Descriptive mark \\
\hline 11. & Mysłowice & MYStOWICE & Initial abbreviations \\
\hline
\end{tabular}




\begin{tabular}{|c|c|c|c|}
\hline 12. & Ruda Śląska & RUDAśląska & Non-figurative mark \\
\hline 13. & Rybnik & Rybnik. Miasto z ikrą. & Metaphoric mark \\
\hline 14. & $\begin{array}{l}\text { Siemianowice Śląs- } \\
\text { kie }\end{array}$ & & Found mark \\
\hline 15. & Sosnowiec & & Non-figurative mark \\
\hline 16. & Świętochłowice & & Non-figurative mark \\
\hline 17. & Tychy & ISCE & $\begin{array}{l}\text { Proper name with } \\
\text { the slogan }\end{array}$ \\
\hline 18. & Zabrze & & Non-figurative mark \\
\hline 19. & Żory & & Proper name \\
\hline
\end{tabular}

Source: Authors of the paper 
Table 2. Counties

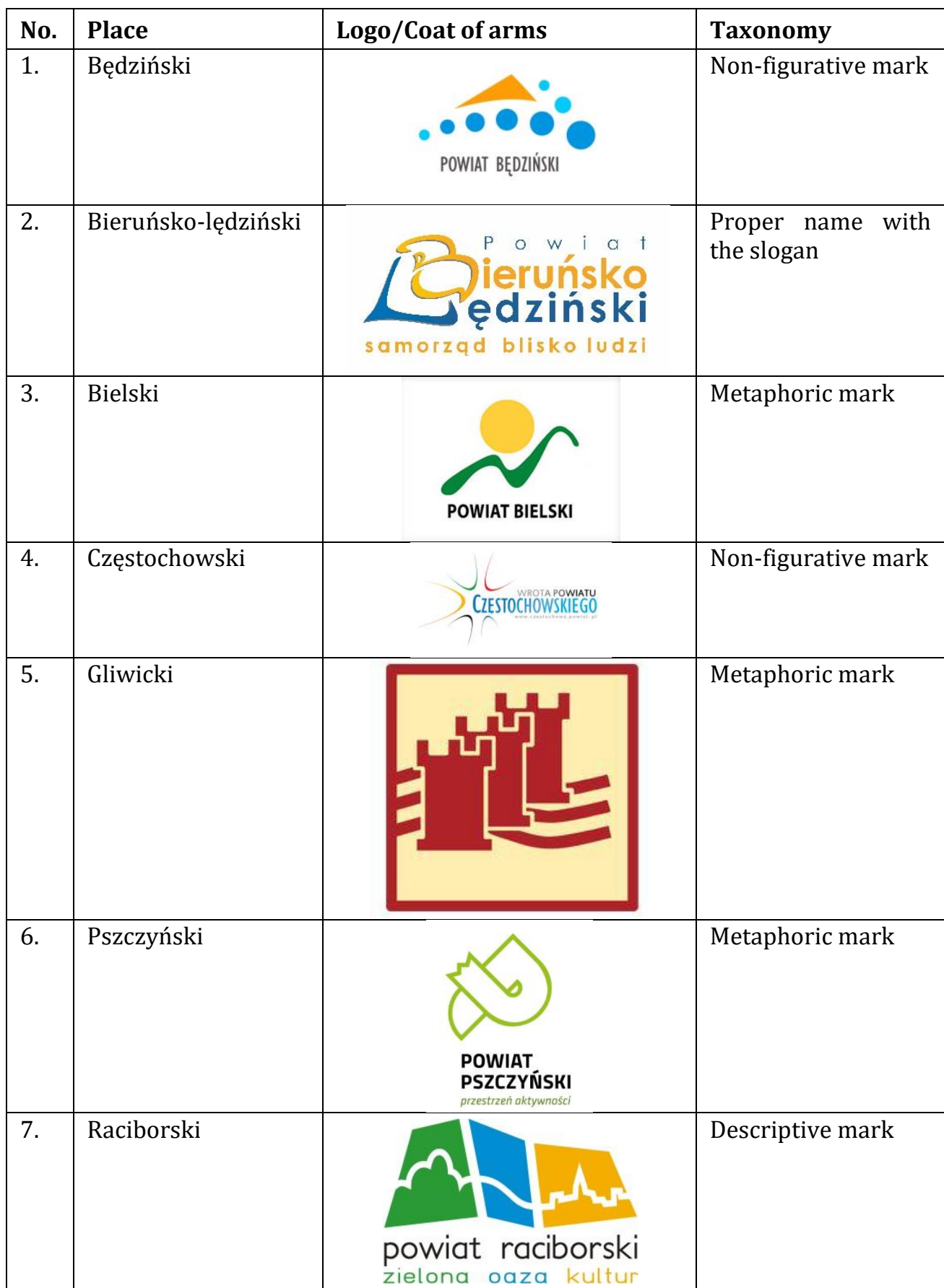




\begin{tabular}{|l|l|l|l|}
\hline 8. & Tarnogórski & Metaphoric mark & \\
\hline 9. & Wodzisławski & & Metaphoric mark \\
\hline 10. & Żywiecki & & Found mark \\
\hline
\end{tabular}

Source: Author's own research

Table 3. Towns and rural communities

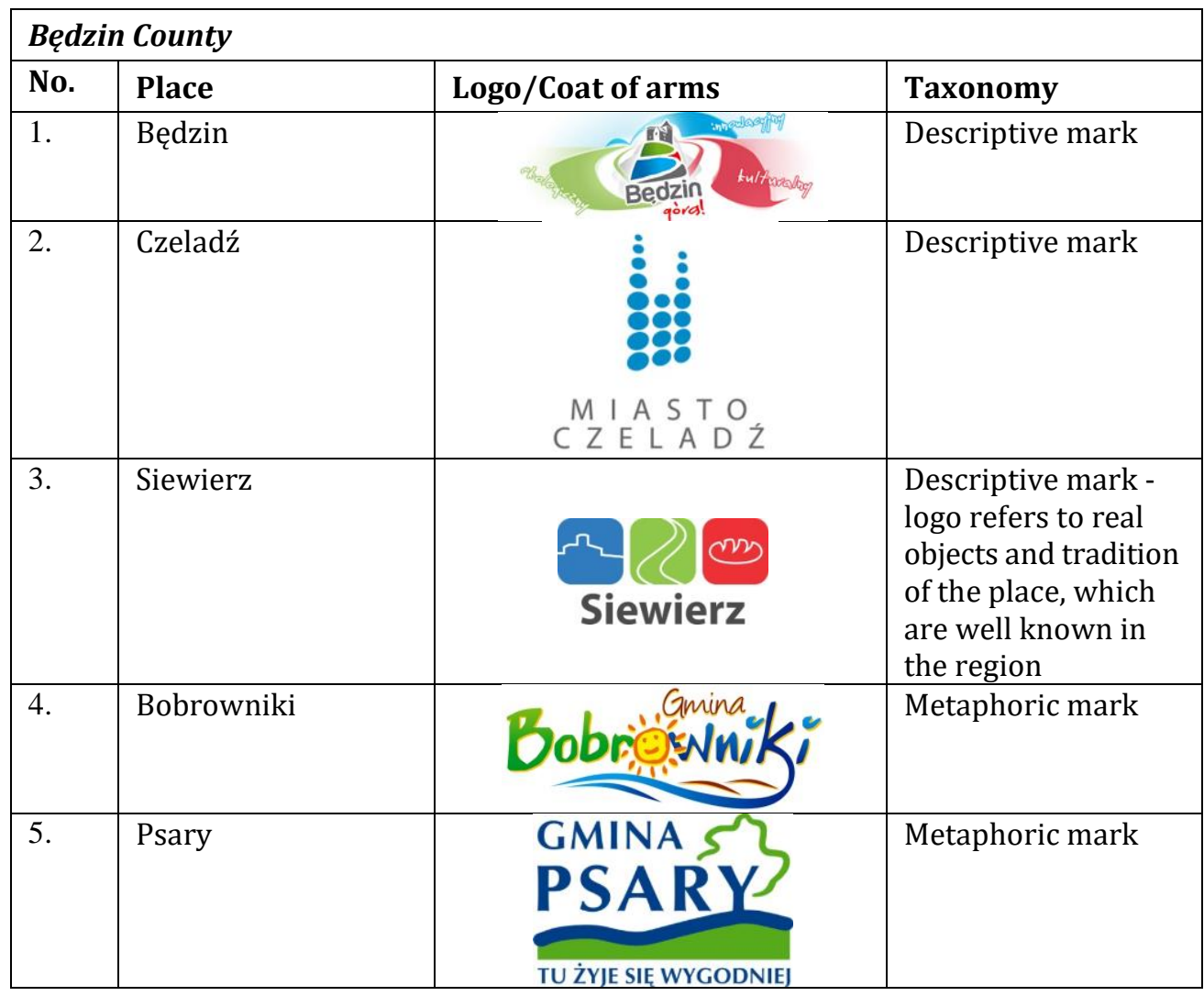


Anna Adamus-Matuszyńska, Piotr Dzik

\begin{tabular}{|l|l|l|l|}
\hline 6. & Wojkowice & Initial abbreviations \\
\hline & $\begin{array}{l}\text { Total number of } \\
\text { communes in the } \\
\text { county without logo, } \\
\text { meaning that they } \\
\text { use coat of arms. }\end{array}$ & 2 & \\
\hline
\end{tabular}

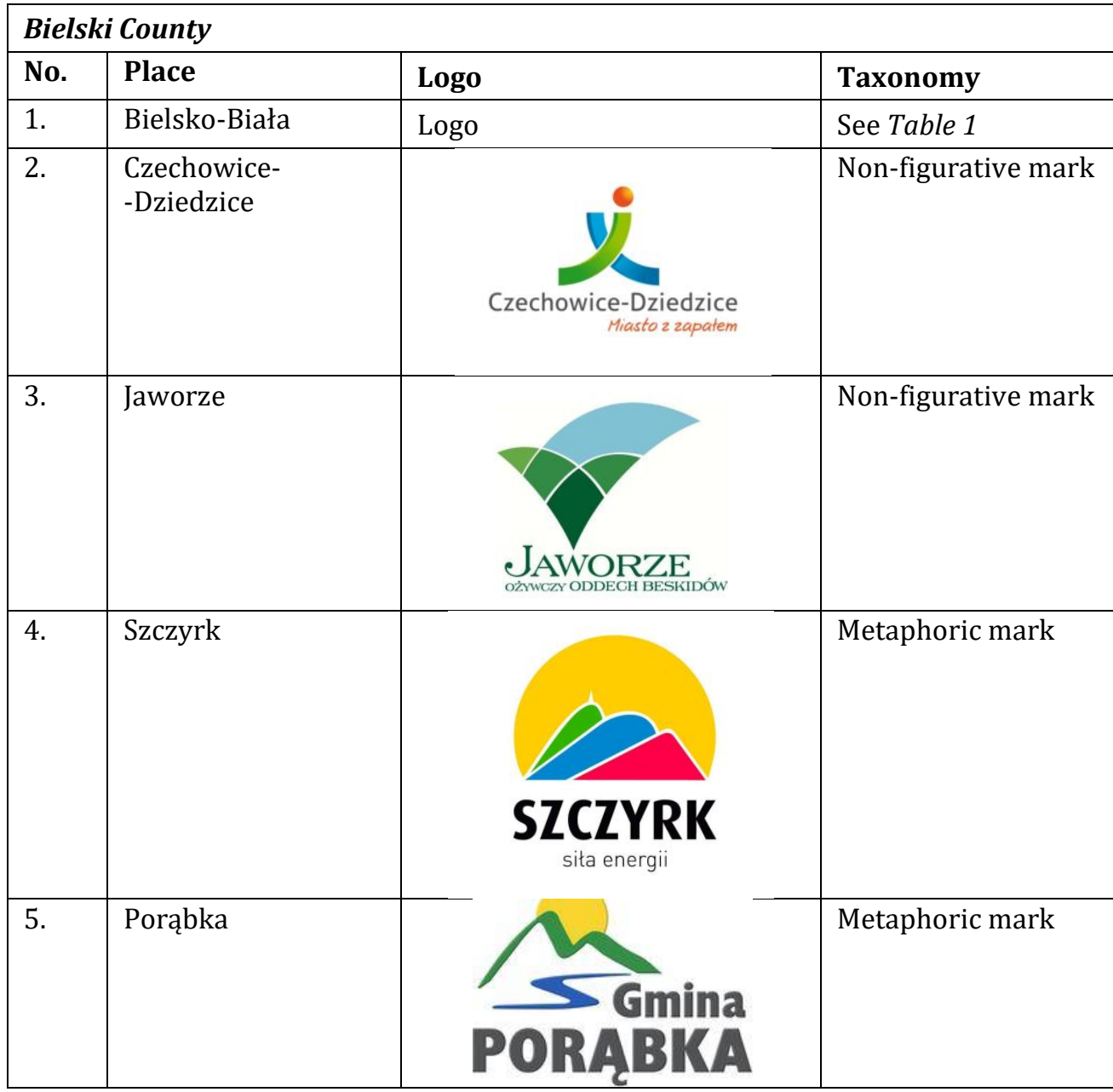




\begin{tabular}{|l|l|l|l|}
\hline 6. & Wilkowice & Metaphoric mark \\
\hline & $\begin{array}{l}\text { Total number of } \\
\text { communes in the } \\
\text { county without logo, } \\
\text { meaning that they } \\
\text { use coat of arms. }\end{array}$ & 5 & \\
\hline
\end{tabular}

\begin{tabular}{|l|l|l|l|}
\hline \multicolumn{3}{|l|}{ Bieruńsko-lędziński County } & Logo \\
\hline No. & Place & & Taxonomy \\
\hline 1. & Bieruń & & Non-figurative mark \\
\hline 2. & Lędziny & $\begin{array}{l}\text { BIERUN } \\
\text { CI PRZAJE }\end{array}$ & Proper name \\
\hline & $\begin{array}{l}\text { Total number of } \\
\text { communes in the } \\
\text { meanty without logo, } \\
\text { use coat of arms. }\end{array}$ & 3 & \\
\hline
\end{tabular}

\begin{tabular}{|l|l|c|l|}
\hline \multicolumn{3}{|l|}{ Cieszyński County } \\
\hline No. & Place & Logo/Coat of arms & Taxonomy \\
\hline 1. & Cieszyn & \\
& & Non-figurative mark \\
& & $\begin{array}{c}\text { CiesZyn } \\
\text { robi wrażenie }\end{array}$ & \\
\hline
\end{tabular}

${ }^{5}$ Cieszyn has another logo see: (http://www.cieszyn.pl/...). There is no clear relation between these two signs. 
Anna Adamus-Matuszyńska, Piotr Dzik

\begin{tabular}{|c|c|c|c|}
\hline 2. & Strumień & strumieñ & Proper name \\
\hline 3. & Wisła & & Metaphoric mark \\
\hline 4. & Brenna & & Metaphoric mark \\
\hline 5. & Istebna & & Metaphoric mark \\
\hline 6. & Ustroń & & Non-figurative mark \\
\hline & & & \\
\hline 7. & Zebrzydowice & & Metaphoric mark \\
\hline & $\begin{array}{l}\text { Total number of } \\
\text { communes in the } \\
\text { county without } \\
\text { logo, meaning that } \\
\text { they use coat of } \\
\text { arms. }\end{array}$ & 5 & \\
\hline
\end{tabular}

\section{Częstochowski County}

\begin{tabular}{|c|c|c|c|}
\hline No. & Place & Logo/Coat of arms & Taxonomy \\
\hline 1. & Częstochowa & Logo & See Table 1 \\
\hline 2. & Konopiska & & $\begin{array}{l}\text { Proper name with the } \\
\text { slogan }\end{array}$ \\
\hline
\end{tabular}




\begin{tabular}{|l|l|l|l|}
\hline 3. & Olsztyn & Found mark \\
\hline & $\begin{array}{l}\text { Total number of } \\
\text { communes in the } \\
\text { county without logo, } \\
\text { meaning that they } \\
\text { use coat of arms. }\end{array}$ \\
\hline
\end{tabular}

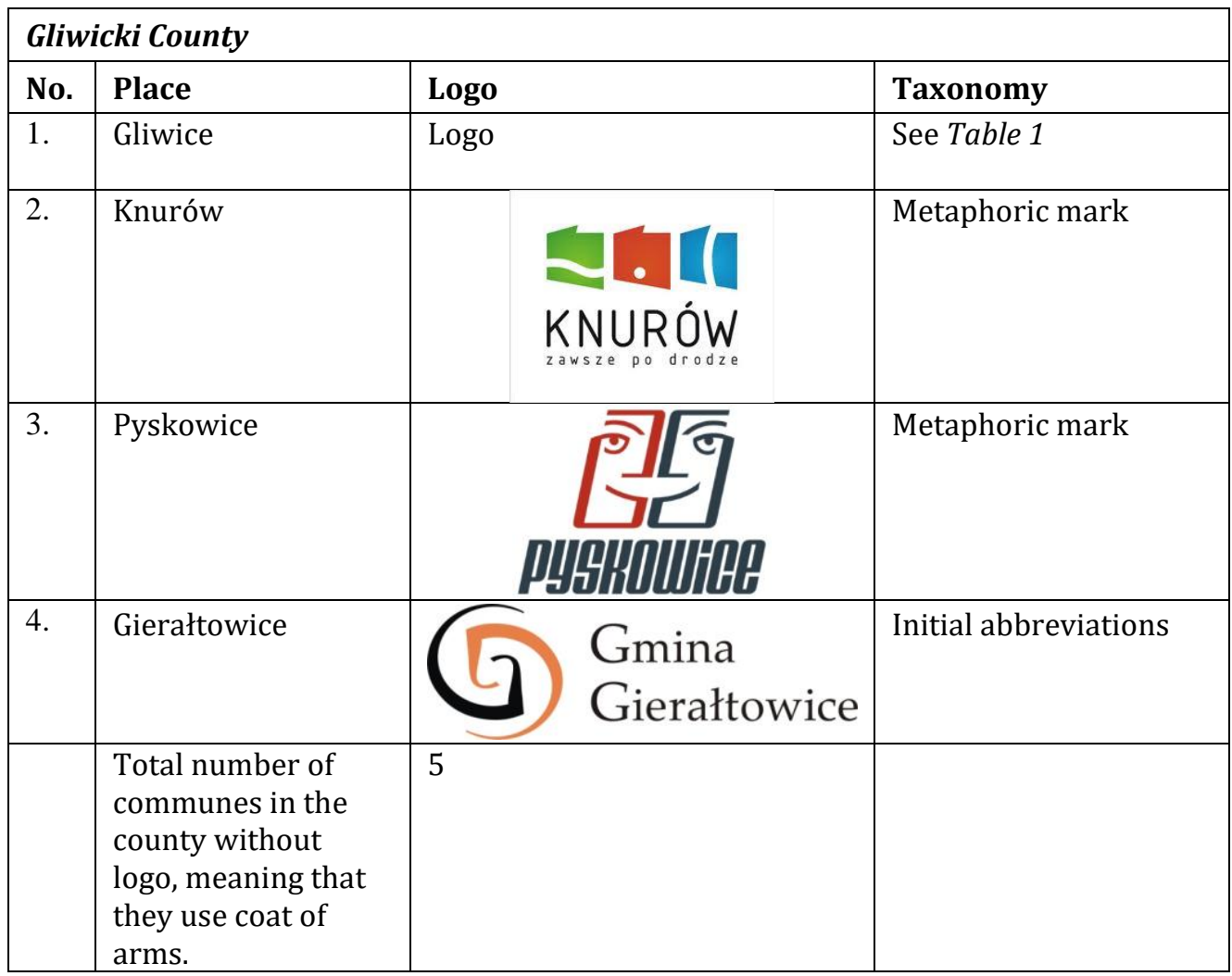




\begin{tabular}{|l|l|l|l|}
\hline \multicolumn{3}{|l|}{ Kłobucki County } & Taxonomy \\
\hline No. & Place & Logo & Found mark \\
\hline 1. & Kłobuck & & $\begin{array}{l}\text { Proper name with the } \\
\text { slogan }\end{array}$ \\
\hline 2. & Panki & $\begin{array}{l}\text { Total number of } \\
\text { communes in the } \\
\text { county without logo, } \\
\text { meaning that they } \\
\text { use coat of arms. }\end{array}$ & 7 \\
\hline
\end{tabular}

\begin{tabular}{|l|l|l|l|}
\hline \multicolumn{3}{|l|}{ Lubliniecki County } \\
\hline No. & Place & Logo & Taxonomy \\
\hline 1. & Lubliniec & Proper name with the \\
slogan
\end{tabular}

\begin{tabular}{|l|l|l|l|}
\hline \multicolumn{3}{|l|}{ Mikołowski County } \\
\hline No. & Place & Logo/Coat of arms & Taxonomy \\
\hline 1. & Ornontowice & 802809 & Metaphoric mark \\
& & & \\
& & Ornontowice & \\
\hline
\end{tabular}




\begin{tabular}{|l|l|l|l|}
\hline 2. & Wyry & $\begin{array}{l}\text { Gmina } \\
\text { dobre miejsce do zamieszkania }\end{array}$ & \\
\hline & $\begin{array}{l}\text { Total number of } \\
\text { communes in the } \\
\text { county without logo, } \\
\text { meaning that they } \\
\text { use coat of arms. }\end{array}$ & 3 & \\
\hline
\end{tabular}

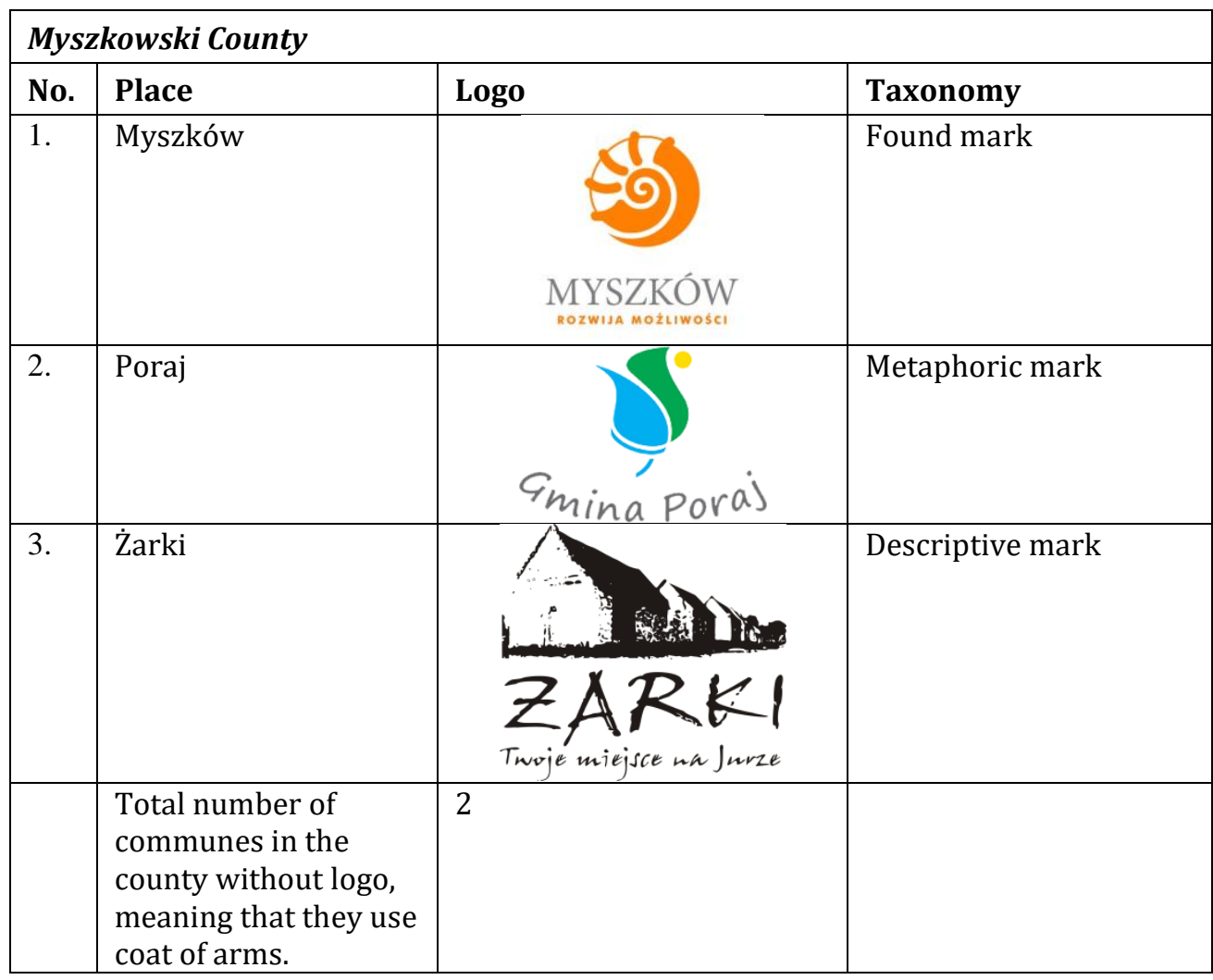




\begin{tabular}{|l|l|l|l|}
\hline \multicolumn{2}{|l|}{ Pszczyński County } & Logo/Coat of arms & Taxonomy \\
\hline No. & Place & Descriptive mark \\
\hline 1. & Pszczyna $^{6}$ & $\begin{array}{l}\text { PSZCZYMA } \\
\text { PERtA KSIEŻN DAISY }\end{array}$ & \\
\hline & $\begin{array}{l}\text { Total number of } \\
\text { communes in the coun- } \\
\text { ty without logo, mean- } \\
\text { ing that they use coat of } \\
\text { arms. }\end{array}$ & 5 & \\
\hline
\end{tabular}

\begin{tabular}{|l|l|l|l|}
\hline \multicolumn{2}{|l|}{ Raciborski County } & Logo/Coat of arms & Taxonomy \\
\hline No. & Place & Racibórz & Mescriptive mark \\
\hline 1. & Kornowac & $\begin{array}{l}\text { Total number of } \\
\text { communes in the } \\
\text { county without logo, } \\
\text { meaning that they use } \\
\text { coat of arms. }\end{array}$ & $\begin{array}{l}\text { KORNOWAC } \\
\text { gmina z widokami }\end{array}$ \\
\hline 2. & 6 & \\
\hline
\end{tabular}

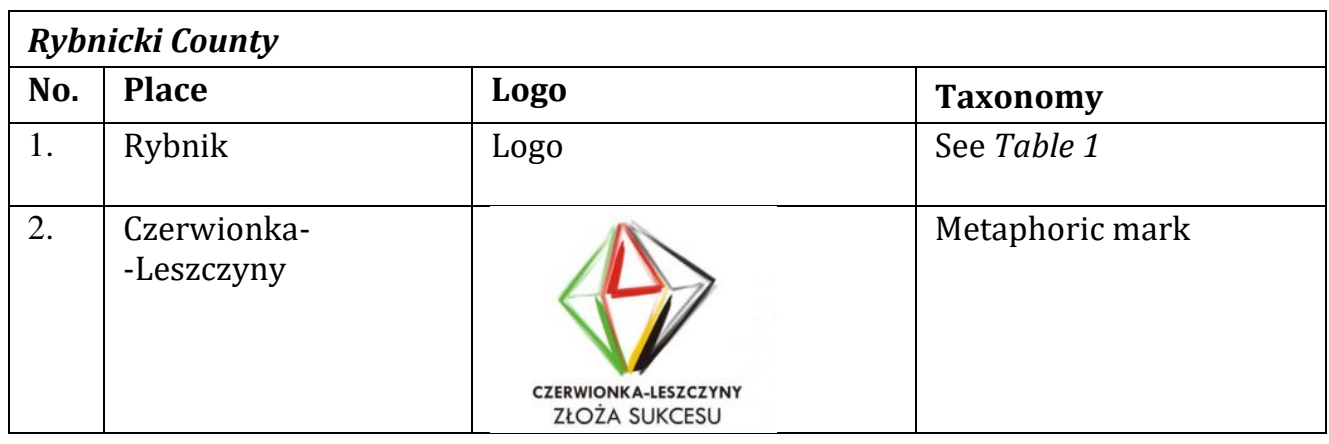

${ }^{6}$ Pszczyna has two different logos, another one is called "logino" and presents a daisy (the flower). See: (http://pszczyna.pl/..., p. 22). 


\begin{tabular}{|l|l|l|l|}
\hline 3. & Gmina Gaszowice & Initial abbreviations \\
\hline 4. & Gmina Lyski & $\begin{array}{l}\text { Gmina } \\
\text { Gaszowice }\end{array}$ & \\
\hline $\begin{array}{l}\text { Tomal number of } \\
\text { county without logo, } \\
\text { meaning that they use } \\
\text { coat of arms. }\end{array}$ & 2 & \\
\hline
\end{tabular}

\begin{tabular}{|c|c|c|c|}
\hline \multicolumn{4}{|c|}{ Tarnogórski County } \\
\hline No. & Place & Logo/Coat of arms & Taxonomy \\
\hline 1. & Kalety & ETY LEŚSYZAKATEK Śl ASKA & Metaphoric mark \\
\hline 2. & Radzionków & & Metaphoric mark \\
\hline & $\begin{array}{l}\text { Total number of } \\
\text { communes in the } \\
\text { county without logo, } \\
\text { meaning that they use } \\
\text { coat of arms. }\end{array}$ & 7 & \\
\hline
\end{tabular}

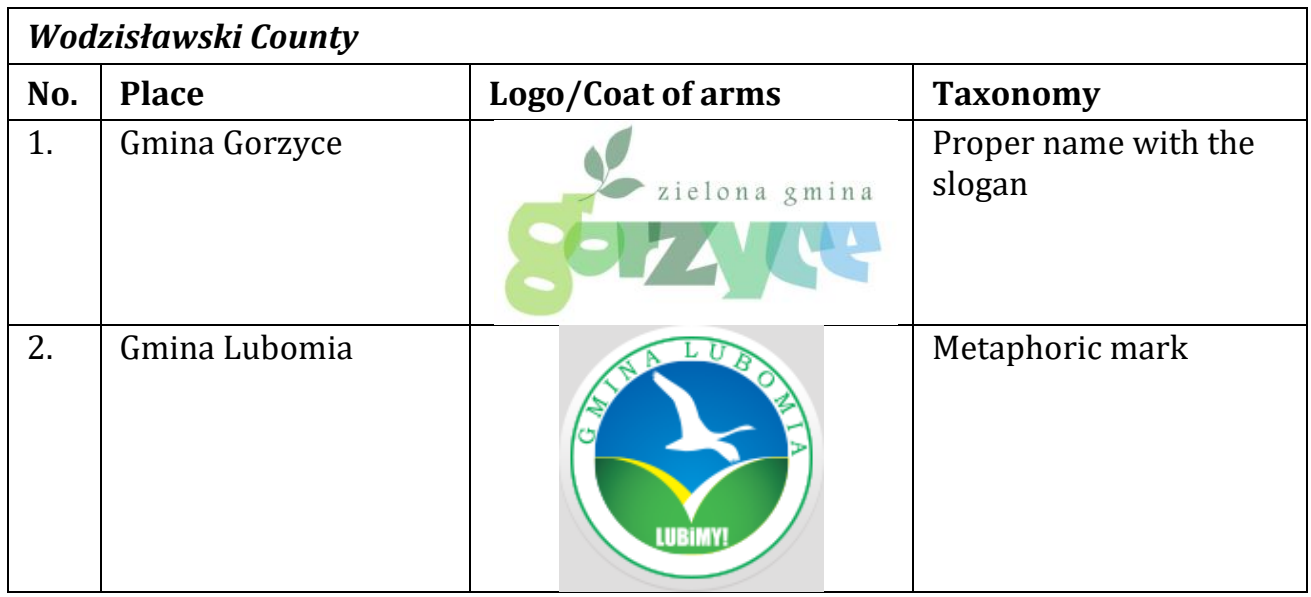


Anna Adamus-Matuszyńska, Piotr Dzik

\begin{tabular}{|c|c|c|c|}
\hline 3. & Mszana & & Metaphoric mark \\
\hline 4. & Wodzisław Śląski & & Metaphoric mark \\
\hline & & $\begin{array}{l}\text { Śląski } \\
\text { Polstri }\end{array}$ & \\
\hline 5. & Radlin & & Metaphoric mark \\
\hline 6. & Rydułtowy & & Metaphoric mark \\
\hline 7. & Godów & & Metaphoric mark \\
\hline & $\begin{array}{l}\text { Total number of } \\
\text { communes in the } \\
\text { county without logo, } \\
\text { meaning that they use } \\
\text { coat of arms. }\end{array}$ & 2 & \\
\hline
\end{tabular}

\section{Zawierciański County}

\begin{tabular}{|l|l|l|l|}
\hline No. & Place & Logo/Coat of arms & Taxonomy \\
\hline 1. & Poręba & DOREB & \\
& & & \\
\hline
\end{tabular}




\begin{tabular}{|l|l|l|l|}
\hline 2. & Zawiercie & Non-figurative mark \\
\hline & $\begin{array}{l}\text { Total number of } \\
\text { communes in the } \\
\text { county without logo, } \\
\text { meaning that they } \\
\text { use coat of arms. }\end{array}$ & 8 & \\
\hline
\end{tabular}

\begin{tabular}{|c|c|c|c|}
\hline \multicolumn{4}{|c|}{ Żywiecki County } \\
\hline No. & Place & Logo/Coat of arms & Taxonomy \\
\hline 1. & Jeleśnia & & Descriptive mark \\
\hline 2. & Lipowa & & Descriptive mark \\
\hline 3. & Radziechowy-Wieprz & $\begin{array}{l}\text { Radziechowy } \cdot \text { Wieprz } \\
\text { Gmina }\end{array}$ & Descriptive mark \\
\hline 4. & Ślemień & asle & Metaphoric mark \\
\hline & $\begin{array}{l}\text { Total number of } \\
\text { communes in the } \\
\text { county without logo, } \\
\text { meaning that they use } \\
\text { coat of arms. }\end{array}$ & 11 & \\
\hline
\end{tabular}

Source: Author's own research 


\section{Analysing the results}

Table 4. Statistical summary

\begin{tabular}{|c|c|c|c|c|c|c|c|c|c|}
\hline \multirow[b]{2}{*}{$\dot{0}$} & \multirow[b]{2}{*}{ 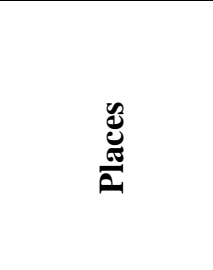 } & \multirow[b]{2}{*}{$\frac{\dot{\Xi}}{\stackrel{\Xi}{\Xi}}$} & \multirow[b]{2}{*}{ 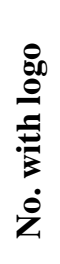 } & \multirow[b]{2}{*}{ 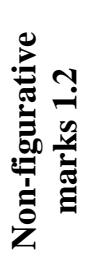 } & \multicolumn{3}{|c|}{ Figurative marks } & \multirow[b]{2}{*}{ 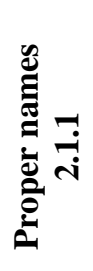 } & \multirow[b]{2}{*}{ : } \\
\hline & & & & & 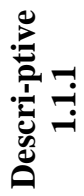 & - & ْ & & \\
\hline 1. & Cities & 19 & 19 & 8 & 3 & 1 & 2 & 4 & 1 \\
\hline 2. & Counties & 17 & 10 & 2 & 1 & 5 & 1 & 1 & 0 \\
\hline 3. & Commu-nities & 148 & 55 & 6 & 10 & 27 & 3 & 6 & 3 \\
\hline & Total & 184 & 84 & 16 & 14 & 33 & 6 & 11 & 4 \\
\hline
\end{tabular}

Source: Author's own research

\section{Discussion and conclusion}

Total numbers of researched units in the Silesia Voivodship are 184. The number of places that use graphic symbols $(\operatorname{logo})$ in their marketing and operational practice is 84 , it means $-45,6 \%$. Compared with the whole country, there are 312 (48\%) among 649 cities and counties that apply graphic symbols in Poland. The statistical difference between the number of towns in Poland and the Silesia Voivodship, which use logo of a place in their promotional activities, is not significant. The main reason is, that large cities in Poland use visual identification in their marketing communication more often because they have more funds to cover the costs.

As it is presented in the provided tables, the figurative marks dominate in visual presentation of Silesian towns. There are 53 of such signs, compared with the non-figurative which is 16 in total. Such situation proves that places (in practice it means self-governments) prefer to demonstrate the objects that actually exist in the region $^{7}$ in graphic symbols.

Fifteen communities and one county use so-called 'landscape' as a visual presentation of the place. It should be stressed that such presentation is not typical for large cities that prefer more abstract visual representation. Moreover, such colours as blue, green, and yellow dominate in visual identity of the Silesia towns. The graphic symbols used are very general and traditional, thus another town in a different region might easily adopt them. It means that such logo does not meet the distinctive function of a logo. From the visual presentation of the Silesian towns and communes one may have difficulty to acknowledge the essentials of the place and its community. Logos are similar and do not let the user make any distinctions among them.

\footnotetext{
${ }^{7}$ Kevin Lynch in The Image of the City stressed that vivid and integrated physical setting place provides raw material to present the place in the process of communication (Lynch 2011, p. 5).
} 
One of the main issues which should be emphasised is connected with the presentation of the place identity. The authors of signs assume that objects presented in particular visual symbols are commonly known and can be easily recognized by the user. They are created with the application of the communication formula called 'what is inside - is known outside'.

Next conclusion is similar to that elaborated by Mattias Beyrow and Constanze Vogt (Beyrow, Vogt 2014, p. 34). The visual representation of a place in a graphic symbol is overloaded. There is much content and the authors want to present all crucial and famous objects. Therefore, one may feel confused when trying to understand what is typical for a given place and what may distinguish a certain place from others.

Graphic signs play an important role in urban and rural spaces, including social space. Thus an examination should concentrate not only on the relationships between place identity and visual identity, but also on their functions in public space. Analysis of the logos and other visual symbols of places should cover sociological, public management and graphic design studies. Such a comprehensive scientific examination will bring complete understanding of both - the process of graphic signs creation and the graphic signs impact on community and socio-economic surroundings. Visual signs represent the place and its community, they uncover the most significant characteristics of the place and its people, they influence perception of others, and finally activate decision-making processes of citizens, tourists and investors. In all, joining together different approaches - graphic design, sociological, cultural, economic and managerial will bring profits for a given place and its community.

New public management is a concept that demonstrates how to manage public values today. This also applies to the management of intangible values. One of such values is the identity of a city or region, expressed, among others, by visual signs symbolizing the best traditions, history, what is important for the residents and the environment. Therefore, the management of visual identity, in the days of the dominance of images in the public space, is used in the impact on the perception of the place, its people, organizations operating there and the existing physical infrastructure and buildings (Eshuis, Klijn 2012, p. 3). The process of brand identity creation is different from the traditional, rational forms of communication, as it must appeal to a person; his/her sensuality and emotions affect his/her impressions. Hence there is this important role of the place visual identity which can support local governments for the development of the place, or if it is wrongly managed - hinder them. 


\section{Literature}

Adamus-Matuszyńska A. (2012), Wstęp do praktyki public relations, Wydawnictwo Uniwersytetu Ekonomicznego w Katowicach, Katowice.

Anholt S., Hildreth J. (2005), Brand America. Tajemnica megamarki, Instytut Marki Polskiej, Warszawa.

Ashworth G., Kavaratzis M. (2009), Beyond the Logo: Brand Management for Cities, "Journal of Brand Management", Vol. 16, Issue 8, p. 520-532. DOI: 10.1057/palgrave.bm. 2550133

Austen A., Frączkiewicz-Wronka A. (2012), Menedżerowie personalni w międzyorganizacyjnych sieciach. Studium organizacji publicznej, „Zarządzanie Zasobami Ludzkimi”, nr 1, p. 29-50.

Bańczyk M. (2009), Uwarunkowania kulturowe i dizajn w kształtowaniu wartości marki narodowej, Poznan, doctorate thesis (in Polish) available in Wielkopolska Biblioteka Cyfrowa, http://www.wbc.poznan.pl/dlibra/docmetadata?id=130972\&from=publication (accessed: 20.02.2012).

Beyrow M., Vogt C. (2014), Stadte und ihre Zeichen. Identitat, Strategie, Logo, Avedition, London.

Borglund E., Olsson K. (2010), Rethinking Place Marketing - A Literature Review, 50th European Regional Science Association Congress, Jönköping, Sweden, 19th-23th August, http://www.ekf.vsb.cz/export/sites/ekf/projekty/cs/weby/esf-0116/databazeprispevku/clanky_ERSA_2010/ERSA2010finalpaper236.pdf (accessed: 05.09.2015). de Chernatony L., McDonald M., Wallace E. (2011), Creating Powerful Brands, Butterworth-Heineman, Oxford.

Dinnie K. (2014), Nation Branding - Concepts, Issues, Practice, Routledge, London

Eshuis J., Klijn E.-H. (2012), Branding in Governance and Public Management, Routledge, London - New York.

Fallon P., Senn F. (2007), Sita kreacji w reklamie, Helion, Gliwice.

Frączkiewicz-Wronka A. (2008), Zarzadzanie publiczne, światto $w$ tunelu czy następna ściana dla sektora publicznego, "Zeszyty Naukowe Wałbrzyskiej Szkoły Zarządzania i Przedsiębiorczości”, nr 11(1), p. 15-26.

Glińska E., Florek M., Kowalewska A. (2009), Wizerunek miasta. Od koncepcji do wdrożenia, Wolters Kluwer, Warszawa.

Govers R., Go F.M. (2005), Projected Destination Image Online: Website Content Analysis of Pictures and Text, "Information Technology \& Tourism", Vol. 7, p. 73-89.

Govers R., Go F.M. (2009), Place Branding. Glocal, Virtual and Physical Identities, Constructed, Imagined and Experienced, Palgrave MacMillan, Basingstoke.

Hankinson G. (2004), Relational Network Brands: Towards a Conceptual Model of Place Brands, "Journal of Vacation Marketing", Vol. 10, No. 2, p. 109-121. DOI: 10.1177/ 135676670401000202

Hankinson G. (2015), Rethinking the Place Branding Construct, [in:] Kavaratzis M., Warnaby G., Ashword G.J. (eds.), Rethinking Place Branding, Springer, Berlin, p. 13-31.

Hanna S., Rowley J. (2008), An Analysis of Terminology Use in Place Branding, "Journal of Place Branding and Public Diplomacy", Vol. 4, No. 1, p. 6-75.

Hanna S., Rowley J. (2011), Towards a Strategic Place Brand-Management Model, "Journal of Marketing Management", Vol. 27, Issue 5-6, p. 458-476. DOI: 10.1080/ 02672571003683797

Healey M. (2008), Podręcznik brandingu, ABE, Warszawa.

http://pszczyna.pl/ver/images/pliki/Strategia/Strategia-final.pdf (accessed: 28.09.2015).

http://www.cieszyn.pl/?p=categoriesShow\&iCategory=277 (accessed: 28.09.2015). 
Hubbard P., Hall T. (1998), The Entrepreneurial City and the New Urban Politics, [in:] Hal T., Hubbard P. (eds.), The Entrepreneurial City: Geographies of Politics, Regime and Representation, John Wiley \& Sons, Chichester, p. 153-174.

Kavaratzis M. (2004), From City Marketing to City Branding: Towards a Theoretical Framework for Developing City Brands, "Place Branding", Vol. 1, Issue 1, p. 58-73. DOI: 10.1057/palgrave.pb.5990005

Kavaratzis M. (2009), Cities and Their Brands: Lessons from Corporate Branding, "Place Branding and Public Diplomacy", Vol. 5, Issue 1, p. 26-37. DOI: 10.1057/pb.2008.3

Kavaratzis M., Ashworth G.J. (2005), City Branding: An Effective of Identity or a Transitory Marketing Trick?, "Tijdschrift voor Ekonomische en Sociale Geografie", Vol. 96, No. 96, p. 506-514. DOI: 10.1111/j.1467-9663.2005.00482.x Kavaratzis M., Ashworth G.J. (2008), Place Marketing: How Did We Get Here and Where Are We Going?, "Journal of Place Management and Development”, Vol. 1, No. 2, p. 150-165. DOI: $10.1108 / 17538330810889989$

Keller K.L. (2003), Brand Synthesis: The Multidimensionality of Brand Knowledge, Lynch K. (2011), Obraz miasta, Archivolta, Kraków. Lash S., Lury C. (2011), Globalny przemyst kulturowy, Wydawnictwo Uniwersytetu Jagiellońskiego, Kraków.

Lucarelli A., Berg P.O. (2011), City Branding: A State-of-the-Art Review of the Research Domain, "Journal of Place Management and Development", Vol. 4, No. 1, p. 9-27. DOI: $10.1108 / 17538331111117133$

Moilanen T., Rainosto S. (2009), How to Brand Nations, Cities and Destinations, Palgrave MacMillan, London. Mollerup P. (2013), Marks of Excellence, Phaidon Press, London.

Olins W. (2009), Podręcznik brandingu. Brand Book, Instytut Marki Polskiej, Warszawa. Pearce Ph.L. (2005), Tourist Behaviour. Themes and Conceptual Schemes, Channel View Publications, Bristol.

Risitano M. (2006), The Role of Destination Branding in the Tourism Stakeholders System, http://www.esade.edu/cedit2006/pdfs2006/papers/paper_risitano_esade_def.pdf (accessed: 30.11.2011)

Rose G. (2010), Interpretacja materiatów wizualnych. Krytyczna metodologia badań nad wizualnościa, Wydawnictwo Naukowe PWN, Warszawa.

Skinner H. (2008), The Emergence and Development of Place Marketing's Confused Identity, "Journal of Marketing Management", Vol. 24, No. 9-10, p. 915-928. DOI: 10.1362/ $026725708 X 381966$

Szromnik A. (2012), Marketing terytorialny. Miasto i region na rynku, Wolters Kluwer, Warszawa.

Trueman M., Cornelius N. (2006), Hanging Baskets Or Basket Cases? Managing the Complexity of City Brands and Regeneration, Working Paper No. 06/13, Bradford University School of Management, June 2006, http://www.bradford.ac.uk/management/research/ research-publications-and-seminars/working-papers/2006/ (accessed: 30.01.2015).

Vuignier R. (2016), Place Marketing and Place Branding: A Systematic (and Tentatively Exhaustive) Literature Review, Working Paper de l'IDHEAP, Version: 5. DOI: 10.13140/ RG.2.1.1164.9529

Wheeler A. (2009), Designing Brand Identity, John Wiley \& Sons, New Jersey. 


\section{ZARZĄDZANIE TOŻSAMOŚCIĄ WIZUALNĄ WOJEWÓDZTWA ŚLĄSKIEGO POPRZEZ REGIONALNE I LOKALNE LOGO}

Streszczenie: Tworzenie spójnych marek regionalnych i miejskich ma kluczowe znaczenie dla miejsc, ponieważ branding miejsca może przyczynić się do sukcesu w turystyce, inwestycjach, a tym samym do rozwoju całego regionu. Studia literaturowe pokazują, że w literaturze przedmiotu występuje luka badawcza dotycząca praktyki stosowania znaków wizualnych używanych w marketingu miejscowym, które powinny przedstawiać miasto, region lub kraj. Artykuł podejmuje próbę omówienia wyzwań, a także słabości w zarządzaniu tożsamością wizualną w województwie śląskim, a pośrednio i w Polsce. Celem badań było zidentyfikowanie oraz analiza logo miast i gmin województwa śląskiego. Głównym celem tej eksploracji jest opisanie śląskiej tożsamości wizualnej poprzez praktykowane wizualne znaki określane terminem „logo”. Autorzy starają się odpowiedzieć pytania badawcze:

1. Jakie trendy są typowe dla wizualnej prezentacji miast $\mathrm{w}$ województwie śląskim?

2. Jaki obraz regionu jest prezentowany w logo śląskich miast?

3. W jaki sposób logo jest stosowane w administracji publicznej w województwie śląskim? W badaniach wykorzystano metodę analizy treści. Najpierw autorzy próbowali zebrać wszystkie logo poprzez obserwację otoczenia zewnętrznego oraz działania samorządów w Interencie, w tym w mediach społecznościowych, a następnie przeanalizować je za pomocą taksonomii Pera Mollerupa. Wyniki badań ilustrują, w jaki sposób instytucje samorządowe odpowiedzialne za promocję miejsca przedstawiają śląskie miasta w komunikacji marketingowej.

Słowa kluczowe: identyfikacja wizualna, logo, marka, marketing miejsca, zarządzanie tożsamością wizualną 